\title{
Alternative food promotes broad mite control on chilli pepper plants
}

\author{
Marcus V. A. Duarte - Madelaine Venzon - Marilia C. de S. Bittencourt • \\ Fredy A. Rodríguez-Cruz $\cdot$ Angelo Pallini $\cdot$ Arne Janssen
}

Received: 15 April 2015/Accepted: 10 July 2015/Published online: 26 July 2015

(C) The Author(s) 2015. This article is published with open access at Springerlink.com

\begin{abstract}
Many omnivorous arthropods are important natural enemies because they can feed on plantprovided pollen and several prey species, and thus persist in crops even in the absence of the target pest. Hence, populations of these predators can be established in a crop by providing alternative food, thus increasing biological control. We investigated how alternative food affects broad mite (Polyphagotarsonemus latus) control on chilli pepper plants by predatory mites. The predatory mite Amblyseius herbicolus had high oviposition and population growth rates when fed with cattail pollen, chilli pepper pollen and bee-collected pollen, and a low rate on the alternative prey Tetranychus urticae. Supplementing pepper plants with pollen resulted in better control of broad mite populations. Release of $A$. herbicolus on young plants with weekly addition of honeybee pollen until
\end{abstract}

Handling Editor: Josep Anton Jaques.

M. V. A. Duarte - M. C. d. S. Bittencourt .

F. A. Rodríguez-Cruz · A. Pallini

Department of Entomology, Federal University of Viçosa,

Viçosa, Minas Gerais, Brazil

M. Venzon · F. A. Rodríguez-Cruz

Agriculture and Livestock Research Enterprise of Minas

Gerais (EPAMIG), Viçosa, Minas Gerais, Brazil

\section{A. Janssen $(\bowtie)$}

IBED, Section Population Biology, University of Amsterdam, Amsterdam, The Netherlands

e-mail: arne.janssen@uva.nl plants produce flowers seems a viable strategy to sustain populations of this predator, thus protecting young, vulnerable plants from broad mite infestations.

Keywords Biological control $\cdot$ Pollen $\cdot$ Spider mites $\cdot$ Polyphagotarsonemus latus $\cdot$ Amblyseius herbicolus $\cdot$ Phytoseiidae

\section{Introduction}

Many important natural enemies in biological control feed on both plant material and prey, for example, predatory bugs (Bonte and De Clercq 2011; Pumariño et al. 2012; Wong and Frank 2013), ladybugs (Burgio et al. 2006; Amaral et al. 2013), lacewings (Venzon et al. 2006; Morgado et al. 2014) and predatory mites (van Rijn and Tanigoshi 1999; Goleva and Zebitz 2013). When feeding on food sources from plants, these omnivorous natural enemies persist longer in the crop than strictly carnivorous enemies, and this can be advantageous for biological control (Symondson et al. 2002; Janssen and Sabelis 2015).

Many plants offer food for natural enemies, such as extrafloral nectar and pollen (Wäckers et al. 2005). The presence of these alternative foods can increase biological control of plant pests by natural enemies (Ramakers 1990; van Rijn et al. 2002; Messelink et al. 2008; Rezende et al. 2014). The presence of alternative foods can increase densities of natural enemies and subsequently cause a reduction of the pest 
populations, a phenomenon similar to apparent competition (Holt 1977; Nomikou et al. 2010), which is an interaction between populations of different prey species mediated by a shared predator (Holt 1977; van Veen et al. 2006; Messelink et al. 2008; Nomikou et al. 2010). In addition to offering a higher quantity of food, the combination of alternative food and prey may provide the predators with a better diet than both single diets, which leads to higher predator densities and better biological control (Messelink et al. 2008). Besides pollen and nectar, other, non-pest, herbivores can also serve as alternative food for predators (Langer and Hance 2004; Park et al. 2011; Goleva and Zebitz 2013). The release of non-pest herbivorous mites as alternative food has already shown its potential as strategy to improve biocontrol (English-Loeb et al. 1993; Karban et al. 1994).

Besides having positive effects on biological control, the presence of alternative food can also result in negative effects (van Maanen et al. 2012). The addition of alternative food can result in satiation of the natural enemies, thus reducing the efficiency of biological control in the short term (so-called apparent mutualism, Abrams and Matsuda 1996). However, in the long term, this often results in positive effects on biological control through apparent competition (van Maanen et al. 2012; Bompard et al. 2013). In the present study, we investigate how adding alternative food (prey or plant based) for predators to a crop plant affects biological control in the short term, thus protecting young plants from becoming infested with an extremely damaging pest.

Our experimental system consisted of chilli pepper (Capsicum frutescens L.), its pest, the broad mite Polyphagotarsonemus latus Banks (Acari: Tarsonemidae), and the omnivorous predatory mite Amblyseius herbicolus Chant (Acari: Phytoseiidae). Chilli pepper is an important crop in (sub) tropical regions. In Brazil, the main production occurs in the state of Minas Gerais, where it is mainly cultivated by small farmers (Pinto et al. 2012). Chilli pepper plants produce pollen that has been shown to serve as alternative food for phytoseiid mites (Xiao et al. 2012; Avery et al. 2014; Kumar et al. 2015).

Chilli pepper plants are attacked by many herbivores such as aphids, whiteflies, mites and fruit borers (Venzon et al. 2011). The broad mite P. latus deserves special attention due to the serious economic damage it causes (Venzon et al. 2011, 2013). Broad mites can feed on more than 60 families of plants (Gerson 1992). They are very small $(0.10-0.30 \mathrm{~mm})$, which makes them hard to detect (de Moraes and Flechtmann 2008), and they are usually noticed only when plants show damage symptoms, which usually is too late to control the broad mites (Venzon et al. 2013). Plants from the genus Capsicum are highly susceptible to damage from these mites: an infestation of ten individuals per plant is sufficient for causing significant damage and reducing the yield of these crops (de Coss-Romero and Peña 1998; Rodríguez-Cruz 2014).

Phytoseiid mites are important natural enemies in many agricultural systems (Helle and Sabelis 1986; de Moraes and Flechtmann 2008). Many phytoseiids are omnivores and are capable of feeding on a wide variety of prey and plant-provided food (McMurtry and Croft 1997; McMurtry et al. 2013). Several predatory mites, such as Neoseiulus cucumeris Oudemans, Amblyseius swirskii Athias-Henriot, Iphiseiodes zulugai Denmark and Muma, Euseius concordis (Chant), N. barkeri Hughes, $N$. californicus (McGregor) and A. herbicolus have shown potential to control broad mite populations (Peña and Osborne 1996; Weintraub et al. 2003; Jovicich et al. 2009; van Maanen et al. 2010; Sarmento et al. 2011; RodríguezCruz 2014). Of those, A. herbicolus is frequently found in association with chilli pepper plants infested with broad mites in Minas Gerais (Matos 2006; Rodríguez-Cruz 2014). It is capable of reproducing and developing when feeding either on pollen or on broad mites (Rodríguez-Cruz et al. 2013), and of significantly reducing broad mite populations under greenhouse and field conditions (Rodríguez-Cruz 2014). However, even these reduced populations consisted of sufficient numbers of broad mites to cause yield reduction in this sensitive crop (de CossRomero and Peña 1998; Rodríguez-Cruz 2014).

We conducted a series of experiments to determine the ability of $A$. herbicolus to reproduce on alternative foods such as (a) honeybee pollen; (b) cattail (Typha sp.) pollen; (c) Tetranychus urticae, a non-pest herbivore on chilli pepper; and (d) chilli pepper pollen, a food source that this predatory mite will encounter on chilli pepper plants in the field. The population growth rate of $A$. herbicolus on these alternative foods on entire plants was also evaluated. We furthermore tested how the best alternative food sources affected the population dynamics of $A$. herbicolus and broad mites, with the objective to 
determine how alternative food affected biological control.

\section{Materials and methods}

Rearing methods

Chilli pepper seeds were sown in polystyrene trays $(8 \times 16$ cells $)$ filled with a commercial substrate (Bioplant $^{\circledR}$, a mixture of vermiculite and organic fertilizer) in a greenhouse. Plants of 21 days old were transplanted to 21 pots filled with the same substrate. Plants were watered daily and a commercial fertilizer (Biofert $^{\circledR}$, 6-4-4 and micronutrients) was applied every 15 days according to the seller's instructions.

We used a commercial dehydrated form of honeybee (Apis mellifera) pollen (Santa Barbara ${ }^{\circledR}$ ). It consisted of a mixture of pollen of various plant species, collected by honeybees. Pollen from a local Typha sp. was collected from plants found in the rural area of Viçosa (Minas Gerais, Brazil, 20 $45^{\prime} 0^{\prime \prime} \mathrm{S}$, $\left.42^{\circ} 52^{\prime} 0^{\prime \prime} \mathrm{W}\right)$. Chilli pepper pollen was collected from recently opened flowers from plants that were grown in a greenhouse. All pollen was dried in an oven at $50{ }^{\circ} \mathrm{C}$ for $48 \mathrm{~h}$ and stored in a refrigerator at $8{ }^{\circ} \mathrm{C}$.

Polyphagotarsonemus latus was obtained from naturally infested chilli pepper plants from greenhouses at the Federal University of Viçosa in 2012 and a rearing was kept in the Laboratory of Entomology at EPAMIG (Agriculture and Livestock Research Enterprise of Minas Gerais). They were reared on chilli pepper plants placed inside cages $(100 \times 70 \times$ $70 \mathrm{~cm})$, covered with fine mesh $(90 \mu \mathrm{m})$ in a greenhouse. New plants were placed in the cages every week and plants with reduced quality due to high mite infestation were removed.

Tetranychus urticae was collected from naturally infested bean plants at the campus of the Federal University of Viçosa in 2002. They were reared on jack bean (Canavalia ensiformis) leaves placed on top of foam pads ( $4 \mathrm{~cm}$ height), covered with cotton wool, which was submersed in a tray $(29 \times 15 \times 4 \mathrm{~cm})$ filled with water. These arenas were kept in a climatecontrolled cabinet $\left(25 \pm 1{ }^{\circ} \mathrm{C}, \quad 70 \pm 10 \% \mathrm{RH}\right.$, 12:12 h L:D). New arenas were made every four days. The leaves from the old arenas were cut into small pieces and placed on top of the leaves in the new arenas, allowing the mites to infest the new leaves.
A rearing of $A$. herbicolus was started with mites kindly provided by A. Rodríguez-Cruz (EPAMIG). They were collected from chilli pepper plants in Viçosa and Oratórios (Minas Gerais, Brazil, 20 $20^{\circ} 5^{\prime} 0^{\prime \prime} \mathrm{S}$, $42^{\circ} 52^{\prime} 0^{\prime \prime} \mathrm{W}$ and $20^{\circ} 24^{\prime} 0^{\prime \prime} \mathrm{S}, 42^{\circ} 48^{\prime} 0^{\prime \prime} \mathrm{W}$ respectively). The rearing was kept on arenas made of PVC sheets $(15 \times 10 \mathrm{~cm})$ on top of foam pads (4 cm height), which were kept in plastic trays $(29 \times 14 \times 4 \mathrm{~cm})$ filled with water. The edges of the arenas were wrapped with wet Kleenex ${ }^{\circledR}$ paper tissue, which was suspended into the water and thus served as both barrier and water source (van Rijn and Tanigoshi 1999). A small tentshaped piece of PVC sheet was placed on the arena to serve as shelter, and a small piece of cotton wool was put under it as oviposition substrate. Typha sp. and honeybee pollen were offered as food. These arenas were kept in a climate-controlled cabinet $\left(25 \pm 1{ }^{\circ} \mathrm{C}\right.$, $70 \pm 10 \%$ RH, 12:12 h L:D).

Oviposition with different food sources

For each repetition, a single female of $A$. herbicolus, ten days old since egg (3-4 days old since adult), was placed on a $3 \mathrm{~cm}$ (diameter) chilli pepper leaf disc with a single food source, which was placed, abaxial side up, in a $5 \mathrm{~cm}$ Petri dish on top of cotton wool in water. A small tent-shaped piece of PVC was placed on the disc to offer shelter, thus reducing predator escape. The arenas were kept in a climate cabinet $\left(25 \pm 1{ }^{\circ} \mathrm{C}, 70 \pm 10 \% \mathrm{RH}\right.$, 12:12 h L:D). The mites were offered ample amounts of chilli pepper pollen, honeybee pollen, Typha sp. pollen or a mixture of different stages of $T$. urticae as food. Food was always remaining at the end of the experiment, indicating that there was always sufficient food available. The mixture of $T$. urticae was obtained by placing twenty adult females on the discs, allowing them to oviposit for two days, and subsequently adding fifteen larvae and deutonymphs. This number of prey was found to be sufficient food in previous experiments. Predator oviposition was recorded daily for three days. Oviposition of the first day was not included in the analysis because it would have been affected by the diet of previous days (Sabelis 1990). The eggs were counted daily while removing them from the arenas. Because these oviposition data did not fit a parametric distribution, a non-parametric Kruskal-Wallis test was used to assess the effect of diet on oviposition, and a Wilcoxon rank sum test with Holm correction was used to compare oviposition on the different food sources. 
Predator population dynamics on chilli pepper plants with different food sources

To evaluate the quality of food sources on plants, the population growth of $A$. herbicolus was assessed on chilli pepper plants (60 days old, approximately $30 \mathrm{~cm}$ high, four pairs of fully expanded leaves) kept in a climate-controlled room $\left(26 \pm 2{ }^{\circ} \mathrm{C}\right.$ and $70 \pm 10 \%$ $\mathrm{RH}$ ). Each treatment had a total of six plants (replicates). In the first treatment, plants had flowers that supplied pollen as food. Flowers were removed from the plants of all other treatments. The second treatment consisted of the addition of honeybee pollen to the plants $(0.15 \mathrm{~g}$ added weekly on the third completely expanded leaf). The third treatment consisted of plants with a mixture of $T$. urticae stages, and the fourth treatment consisted of plants containing no food (control). The mixture of T. urticae was obtained by placing $200 \mathrm{~T}$. urticae females on the plants and allowing them to oviposit for one week before the experiment, thus all stages were present during the experiment. The plants were placed in water-filled trays to avoid escape of mites and migration to other plants. Five A. herbicolus females (ten days old since egg) were placed on each plant. On the second, third, fourth, sixth and eighth day, the number of motile predators was assessed on the entire intact plants using a hand-held $\times 10$ magnifying glass. The numbers of predators per plant were compared among treatments with a linear mixed-effects model with treatment as fixed factor and plant identity as random factor to correct for repeated measures. On the tenth day, the plants were taken to the laboratory, the leaves were removed one by one and the motile stages of the predatory mites were counted using a stereoscopic microscope (Zeiss ${ }^{\circledR}$ Stemi 2000-c). The numbers of predators found during this destructive sampling did not fit any parametric distribution and were analysed using a non-parametric Kruskal-Wallis ANOVA followed by a pairwise Wilcoxon rank sum test with Holm correction to compare the different treatments.

\section{Population dynamics of $P$. latus and A. herbicolus} in the presence of alternative food

The dynamics of broad mites and predators was studied on intact chilli pepper plants (90 days old, approximately $40 \mathrm{~cm}$ high, eight pairs of fully expanded leaves), which received the following treatments: (a) plants without flowers or pollen (control), (b) plants without flowers but with honeybee pollen (as described above), and (c) plants with flowers but without honeybee pollen. Each treatment had eight plants (replicates) and each plant received five ten-day-old $A$. herbicolus females. Ten days later, plants were infested with twenty adult $P$. latus females. Seven and fourteen days after this infestation, three leaves were removed from the top third and from the middle third of the plant, the number of eggs and motile mites (both species) and quiescent larvae (for $P$. latus) were counted using a stereoscopic microscope as described above. These leaves were chosen because the majority of predators were found on them in the previous experiment. Broad mites are usually found on new leaves near the top of the plant. This experiment was also done in a climate-controlled room $\left(26 \pm 2^{\circ} \mathrm{C}\right.$ and $\left.70 \pm 10 \% \mathrm{RH}\right)$. The numbers of mites were compared among treatments with a linear mixed-effects model with treatment as fixed factor and plant identity as a random factor to correct for repeated measures. Non-significant interactions and factors were removed from the model, and contrasts among treatments were assessed by stepwise model simplification through aggregation of nonsignificant factor levels (Crawley 2013). All statistical analyses were done using the computer software $\mathrm{R}$ version 3.1.0 (R Core Team 2014).

\section{Results}

Oviposition with different food sources

Diet significantly affected the oviposition of $A$. herbicolus (Fig. 1: Kruskal-Wallis ANOVA, $\left.\chi^{2}=36.9, \mathrm{df}=3, \mathrm{p}<0.001\right)$. Treatments with pollen (honeybee, chilli pepper and Typha sp.) did not differ significantly from each other, whereas $A$. herbicolus feeding on $T$. urticae had a lower oviposition rate than in the other treatments (Fig. 1).

Predator population dynamics on chilli pepper plants with different food sources

The different food sources affected the numbers of predators (Fig. 2a: $\mathrm{F}_{3,20}=70.5, \mathrm{p}<0.001$ ). Time also had a significant effect on the numbers of predators $\left(\mathrm{F}_{1,140}=5.6, \mathrm{p}<0.05\right)$, as had the 


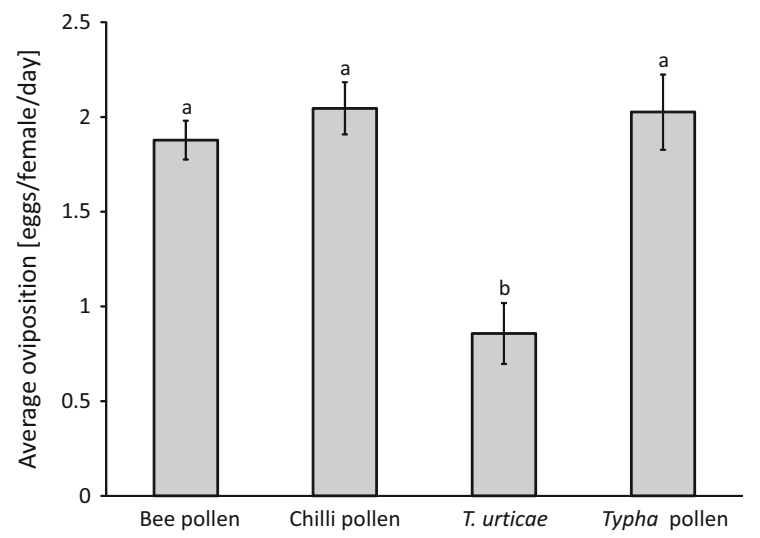

Fig. 1 Average oviposition ( $\pm \mathrm{SE}$ ) by Amblyseius herbicolus on the 2nd and 3rd day of feeding on a diet of bee pollen (20 replicates), chilli pepper pollen (22), a mixture of all stages of $T$. urticae (14) or Typha sp. pollen (19). Bars with different letters indicate significant differences among diets (Wilcoxon rank sum test with Holm correction; $\mathrm{p}<0.05$ )

interaction between time and treatment $\left(\mathrm{F}_{3,155}=108.8, \mathrm{p}<0.001\right)$. This interaction was caused by the increase of the populations in the treatments with honeybee pollen and chilli pepper flowers, whereas the populations in the treatment with T. urticae and in the control did not increase (Fig. 2a). The numbers of predators on plants without food (control) was lower than in the other treatments (Fig. 2a). Plants with flowers or honeybee pollen had the highest numbers of predators, followed by plants infested with T. urticae (Fig. 2a).

The destructive sampling also showed that the numbers of predators differed among treatments (Fig. 2b: Kruskal-Wallis ANOVA, $\chi^{2}=20.91$, df $=3, p<0.001$ ) and confirmed the results presented above. The number of motile predators differed significantly among all treatments, was highest when honeybee pollen was added as alternative food, slightly but significantly lower with pepper flowers, low in the treatment with T. urticae and lowest without alternative food (control) (Fig. 2b).

\section{Population dynamics of $P$. latus and A. herbicolus} in the presence of alternative food

Because time did not have a significant effect on the total number of $P$. latus (LME, likelihood ratio $=0.7, \mathrm{df}=3$, $\mathrm{p}=0.88$ ) or A. herbicolus (LME, likelihood ratio $=3.9$, df $=3, \mathrm{p}=0.28$ ), we combined data from day 7 and day 14 by using the average numbers of the two days. The (a)
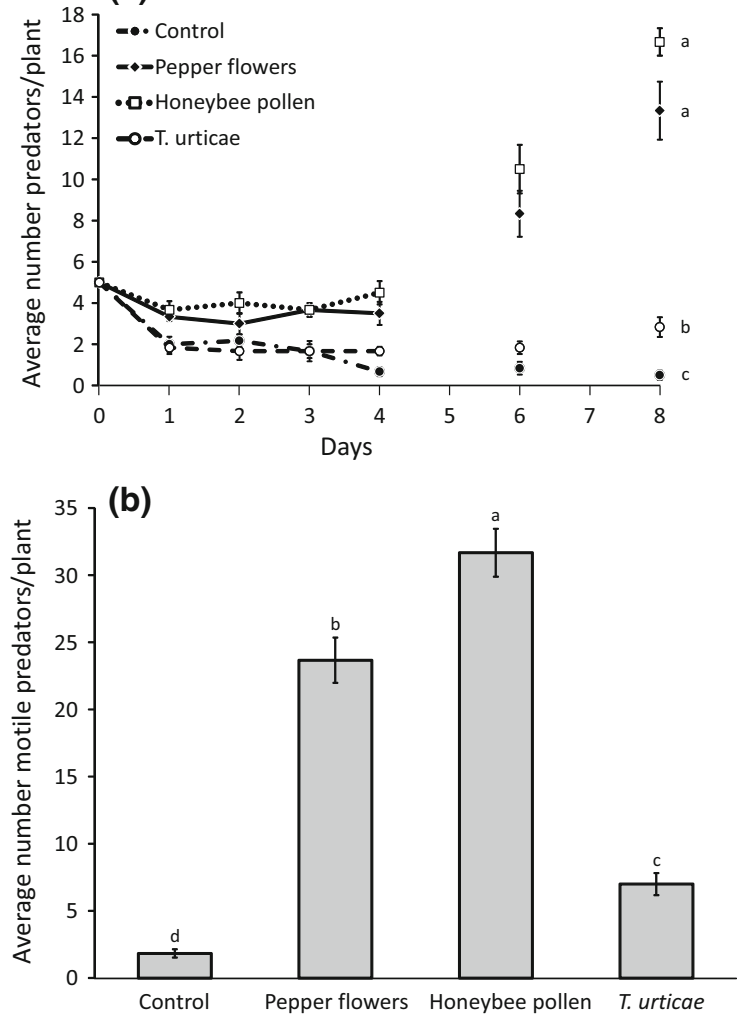

Fig. 2 a Average number of motile Amblyseius herbicolus $( \pm \mathrm{SE}$ ) on chilli pepper plants without flowers or food (control), on plants with flowers supplying pollen, on plants supplied with honeybee pollen, and on plants with a population of T. urticae. Lines with different letters differ significantly through time (contrast after LME; $\mathrm{p}<0.05$ ). b Average numbers of motile $A$. herbicolus $( \pm \mathrm{SE})$ on chilli pepper plants with different food sources at the end of the experiment (destructive sampling). Bars with different letters indicate a significant difference among the treatments (Wilcoxon rank sum test with Holm correction; $\mathrm{p}<0.05$ )

total number of $P$. latus differed significantly among treatments (Fig. 3, LME, likelihood ratio $=59.1$, $\mathrm{df}=2, \mathrm{p}<0.001)$. The number of $P$. latus was higher in the control treatment without alternative food than in the treatments with pepper flowers or honeybee pollen, which did not differ significantly from each other (Fig. 3). The experiment was terminated because plants of the control treatment were dying, whereas there were no visual symptoms of broad mite damage in the treatments with alternative food.

Densities of $A$. herbicolus also differed significantly among treatments (Fig. 3: LME Likelihood ratio $=37.0 ; \mathrm{df}=2 ; \mathrm{p}<0.001)$. The number of predators was lower in the control than in the other 


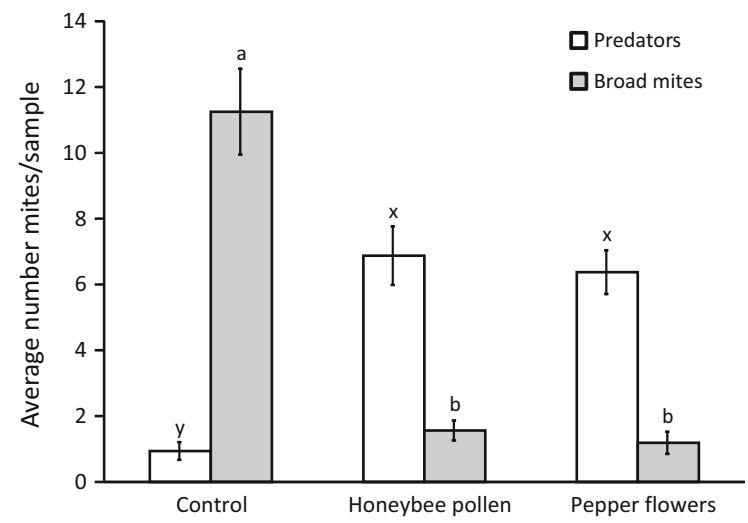

Fig. 3 Average numbers of Polyphagotarsonemus latus (adults, larvae, quiescent larvae and eggs) $( \pm \mathrm{SE})$ and motile predators and eggs on plants without food (control), on plants with flowers providing pollen and on plants supplied with honeybee pollen. Bars with different letters indicate a significant difference among treatments for $P$. latus and predators separately (contrast after LME; $\mathrm{p}<0.01$ )

treatments, which did not differ significantly from each other (Fig. 3).

\section{Discussion}

As shown previously, pollen is an excellent food source for predatory mites (van Rijn and Tanigoshi 1999; Nomikou et al. 2003; Gnanvossou et al. 2005; Rodríguez-Cruz et al. 2013). Here, A. herbicolus reached the highest oviposition rates when the mites were feeding on pollen (honeybee, Typha sp. or chilli pepper) and lower when feeding on T. urticae. When these food sources were offered on entire chilli pepper plants, the results were consistent with those found in the oviposition experiment. Honeybee pollen and chilli pepper pollen were superior food sources compared to T. urticae. It is known that A. herbicolus is not able to develop to adulthood when fed only with T. urticae (Oliveira et al. 2009), possibly because it cannot cope with the web produced by $T$. urticae. We found persistence of $A$. herbicolus populations on chilli pepper plants with a population of $T$. urticae, but the numbers did not increase as much as on the plants with honeybee pollen or with flowers. Therefore, the use of $T$. urticae as an alternative food for $A$. herbicolus is less promising than the use of pollen, not only because of its inferior quality, but also due to the necessity of rearing this herbivore, whereas honeybee pollen is commercially available.
There have been mixed results regarding the quality of bee pollen as food for phytoseiid predators (Ramakers 1995; Goleva and Zebitz 2013). We routinely use bee pollen to rear other predatory mite species, hence the capacity to feed and reproduce on bee pollen is not unique for A. herbicolus. Rather, we think that the pollen used here may be of better quality than those in other studies. Although we do not know its exact composition, the pollen originated from a mixture of native Brazilian plants. Moreover, we dried the pollen before usage (see "Materials and methods" section) and this may prevent the growth of fungi on the pollen.

Amblyseius herbicolus was already known for its potential to control broad mites on chilli peppers in greenhouses and in the field (Rodríguez-Cruz 2014). In a field experiment where chilli peppers were infested with broad mites before the release of $A$. herbicolus, a reduction of the number of broad mites was found on plants where the predators were released, yet the control of broad mites was not sufficient (de Coss-Romero and Peña 1998; Rodríguez-Cruz 2014). This might have been caused by the plant having already been infested with broad mites prior to the release of predators. Because pepper plants are extremely sensitive to broad mite damage, this infestation probably caused significant damage. Hence, predators should preferably be present on the plants before infestation with broad mites occurs, but for such populations to persist, predators need alternative food. We show here that establishing predator populations on pepper plants with alternative food before infestation by the pest indeed results in effective control: the numbers of broad mites per plant in treatments with alternative food were all low (Fig. 3), and plants did not show symptoms of broad mite damage. Because pepper plants themselves provide such food, i.e. pollen, predators can be released on the plants when they start flowering (Ramakers 1990). However, infestation by broad mites can occur before flowering. Hence, early releases of $A$. herbicolus with the addition of honeybee pollen can possibly prevent infestations by the broad mite, as our results indeed show (Fig. 3).

Previous work has demonstrated how pollen can be used to improve biocontrol (van Rijn et al. 2002; Duso et al. 2004; González-Fernández et al. 2009; Nomikou et al. 2010; Delisle et al. 2015; Leman and Messelink 2015) and that the presence of flowers can result in 
persistence of populations of predatory mites on plants without pests (Ramakers 1990; Xiao et al. 2012; Avery et al. 2014; Kumar et al. 2015). Here, we demonstrate that this increment in the number of predatory mites in the absence of the prey can be a strategy to protect plants from pest infestations, similar to what was found by Ramakers (1990) for thrips. Instead of supplying alternative food on the plants, intercropping with other plant species that provide alternative food can also be used to enable early establishment of predators (Landis et al. 2000; Norris and Kogan 2005; Amaral et al. 2013; González-Fernández et al. 2009; Jonsson et al. 2009; Rezende et al. 2014). This remains to be investigated for pepper cropping systems.

Early releases of A. herbicolus on young pepper plants and a weekly addition of honeybee pollen could be sufficient to maintain the predatory mites on chilli pepper plants until these start flowering. Chilli pepper flowers face the leaves under the flowers, allowing their pollen to rain down on the leaves. Given that pollen is a good food source for predatory mites (van Rijn and Tanigoshi 1999; Nomikou et al. 2003; Gnanvossou et al. 2005), the production of excess of pollen could be a trait that evolved as an indirect plant defence (Sabelis et al. 1999, 2011).

Large-scale experiments in the greenhouse or in the field are needed to verify if the addition of food and predatory mites results in better control of broad mite populations. There is the risk involved that other organisms may profit from the pollen supplied, which is not necessarily to the benefit of the plant or of pest control. These competitors for pollen can potentially feed on the predatory mite of interest (intraguild predation) or monopolize the resource, making it more difficult for $A$. herbicolus to benefit from it and consequently protect the plant (van Rijn et al. 2002). If the phenomenon shown here also holds at larger spatial scales and within the context of the community of herbivores, predators and omnivores occurring on pepper plants, the release of predatory mites along with honeybee pollen prior to the infestation, followed by the weekly addition of this pollen until the plants start to produce flowers, is a promising strategy for pest management.

Acknowledgments We thank two anonymous reviewers for their constructive comments. MVAD was supported by Coordination for the Improvement of Higher Level Personnel (Capes, Brazil), AJ by the Minas Gerais State Foundation for Research Aid (FAPEMIG CBB-30003/09), MV, FAR-C and AP were supported by the National Council of Scientific and Technological Development (CNPq).

Open Access This article is distributed under the terms of the Creative Commons Attribution 4.0 International License (http:// creativecommons.org/licenses/by/4.0/), which permits unrestricted use, distribution, and reproduction in any medium, provided you give appropriate credit to the original author(s) and the source, provide a link to the Creative Commons license, and indicate if changes were made.

\section{References}

Abrams PA, Matsuda H (1996) Positive indirect effects between prey species that share predators. Ecology 77:610-616

Amaral DSSL, Venzon M, Duarte MVA, Sousa FF, Pallini A, Harwood JD (2013) Non-crop vegetation associated with chili pepper agroecosystems promote the abundance and survival of aphid predators. Biol Control 64:338-346

Avery PB, Kumar V, Xiao Y, Powel CA, McKenzie CL, Osborne LS (2014) Selecting an ornamental pepper banker plant for Amblyseius swirskii in floriculture crops. Arthropod-Plant Interact 8:49-56

Bompard A, Jaworski CC, Bearez P, Desneux N (2013) Sharing a predator: can an invasive alien pest affect the predation on a local pest? Popul Ecol 55:433-440

Bonte M, De Clercq P (2011) Influence of predator density, diet and living substrate on developmental fitness of Orius laevigatus. J Appl Entomol 135:343-350

Burgio G, Ferrari R, Boriani L, Pozzati M, van Lenteren J (2006) The role of ecological infrastructures on Coccinellidae (Coleoptera) and other predators in weedy field margins within northern Italy agroecosystems. Bull Insectol 59:59-67

Crawley MJ (2013) The R book. Wiley, Chichester

de Coss-Romero M, Peña JE (1998) Relationship of broad mite (Acari: Tarsonemidae) to host phenology and injury levels in Capsicum annuum. Fla Entomol 81:515-525

de Moraes GJ, Flechtmann CH (2008) Manual de Acarologia. Acarologia básica e ácaros de plantas cultivadas no Brasil. Holos, Ribeirão Preto

Delisle JF, Shipp L, Brodeur J (2015) Apple pollen as a supplemental food source for the control of western flower thrips by two predatory mites, Amblyseius swirskii and Neoseiulus cucumeris (Acari: Phytoseiidae), on potted chrysanthemum. Exp Appl Acarol 65:495-509

Duso C, Malagnini V, Paganelli A, Aldegheri L, Bottini M, Otto S (2004) Pollen availability and abundance of predatory phytoseiid mites on natural and secondary hedgerows. BioControl 49:397-415

English-Loeb GM, Karban R, Hougen-Eitzman D (1993) Direct and indirect competition between spider mites feeding on grapes. Ecol Appl 3:699-707

Gerson U (1992) Biology and control of the broad mite, Polyphagotarsonemus latus (Banks) (Acari: Tarsonemidae). Exp Appl Acarol 13:163-178

Gnanvossou D, Hanna R, Yaninek SJ, Toko M (2005) Comparative life history traits of three neotropical phytoseiid 
mites maintained on plant-based diets. Biol Control 35:32-39

Goleva I, Zebitz CPW (2013) Suitability of different pollen as alternative food for the predatory mite Amblyseius swirskii (Acari: Phytoseiidae). Exp Appl Acarol 61:259-283

González-Fernández JJ, de la Peña F, Hormaza JI, Boyero JR, Vela JM, Wong E, Trigo MM, Monteserrat M (2009) Alternative food improves the combined effect of an omnivore and a predator on biological pest control. A case study in avocado orchards. Bull Entomol Res 99:433-444

Helle W, Sabelis MW (eds) (1986) Spider mites: their biology, natural enemies and control volume B. Elsevier Science Ltd, Amsterdam, New York

Holt RD (1977) Predation, apparent competition, and the structure of prey communities. Theor Popul Biol 12:197229

Janssen A, Sabelis MW (2015) Alternative food and biological control by generalist predatory mites: the case of Amblyseius swirskii. Exp Appl Acarol 65:413-418

Jonsson M, Wratten SD, Robinson KA, Sam SA (2009) The impact of floral resources and omnivory on a four trophic level food web. Bull Entomol Res 99:275-285

Jovicich E, Cantliffe DJ, Osborne LS, Stoffella PJ, Simonne EH, Mason PG, David R (2009) Release of Neoseiulus californicus on pepper transplants to protect greenhousegrown crops from early broad mite (Polyphagotarsonemus latus) infestations. In: Proceedings of third international symposium on biological control of arthropods, Christchurch, New Zealand, pp 347-353

Karban R, Hougen-Eitzmann D, English-Loeb G (1994) Predator-mediated apparent competition between two herbivores that feed on grapevines. Oecologia 97:508-511

Kumar V, Xiao Y, McKenzie CL, Osborne LS (2015) Early establishment of the phytoseiid mite Amblyseius swirskii (Acari: Phytoseiidae) on pepper seedlings in a Predator-inFirst approach. Exp Appl Acarol 65:465-481

Landis DA, Wratten SD, Gurr GM (2000) Habitat management to conserve natural enemies of arthropod pests in agriculture. Annu Rev Entomol 45:175-201

Langer A, Hance T (2004) Enhancing parasitism of wheat aphids through apparent competition: a tool for biological control. Agric Ecosyst Environ 102:205-212

Leman A, Messelink G (2015) Supplemental food that supports both predator and pest: a risk for biological control? Exp Appl Acarol 65:511-524

Matos CHC (2006) Mecanismos de defesa constitutiva em espécies de pimenta Capsicum e sua importância no manejo do ácaro branco Polyphagotarsonemus latus (Banks, 1904) (Acari: Tarsonemidae). Thesis Federal University of Viçosa, Brazil

McMurtry JA, Croft BA (1997) Life-styles of phytoseiid mites and their roles in biological control. Annu Rev Entomol 42:291-321

McMurtry JA, de Moraes GJ, Sourassou NF (2013) Revision of the lifestyles of phytoseiid mites (Acari: Phytoseiidae) and implications for biological control strategies. Syst Appl Acarol 18:297-320

Messelink GJ, van Maanen R, van Steenpaal SEF, Janssen A (2008) Biological control of thrips and whiteflies by a shared predator: two pests are better than one. Biol Control 44:372-379
Morgado LN, Resendes R, Moura M, Ventura MAM (2014) Pollen resources used by Chrysoperla agilis (Neuroptera: Chrysopidae) in the Azores, Portugal. Eur J Entomol 111:143-146

Nomikou M, Janssen A, Sabelis MW (2003) Phytoseiid predators of whiteflies feed and reproduce on non-prey food sources. Exp Appl Acarol 31:15-26

Nomikou M, Sabelis MW, Janssen A (2010) Pollen subsidies promote whitefly control through the numerical response of predatory mites. BioControl 55:253-260

Norris RF, Kogan M (2005) Ecology of interactions between weeds and arthropods. Annu Rev Entomol 50:479-503

Oliveira H, Fadini MAM, Rezende D, Giraldo-Soto A, Peréz KG, Aramaendes H, Pallini A (2009) Biologia do ácaro predador Amblyseius herbicolus alimentado por pólen e pela presa Tetranychus urticae. Temas Agrar 14:1-12

Park HH, Shipp L, Buitenhuis R, Ahn JJ (2011) Life history parameters of a commercially available Amblyseius swirskii (Acari: Phytoseiidae) fed on cattail (Typha latifolia) pollen and tomato russet mite (Aculops lycopersici). J Asia-Pac Entomol 14:497-501

Peña JE, Osborne L (1996) Biological control of Polyphagotarsonemus latus (Acarina: Tarsonemidae) in greenhouses and field trials using introductions of predacious mites (Acarina: Phytoseiidae). Entomophaga 41:279-285

Pinto CMF, Pinto CL, Donzeles SML (2012) Boas práticas agrícolas na producao de pimentas. Pimentas: do produtor ao consumidor. Informe Agropecuário, EPAMIG, Belo Horizonte, Brazil

Pumariño L, Alomar O, Lundgren JG (2012) Effects of floral and extrafloral resource diversity on the fitness of an omnivorous bug, Orius insidiosus. Entomol Exp Appl 145:181-190

R Core Team (2014) R: a language and environment for statistical computing. R Foundation for Statistical Computing, Vienna, Austria. http://www.R-project.org/

Ramakers PMJ (1990) Manipulation of phytoseiid thrips predators in the absence of thrips. Bulletin SROP (Fr) 5:169-172

Ramakers PMJ (1995) Biological control using oligophagous predators. In: Parker BL, Skinner M, Lewis T (eds) Thrips biology and management. Springer, New York, pp 225-229

Rezende MQ, Venzon M, Perez AL, Cardoso IM, Janssen A (2014) Extrafloral nectaries of associated trees can enhance natural pest control. Agric Ecosyst Environ 188:198-203

Rodríguez-Cruz FA (2014) Biological control of broad mites in chili pepper and physic nut. Thesis Federal University of Viçosa, Brazil

Rodríguez-Cruz FA, Venzon M, Pinto CMF (2013) Performance of Amblyseius herbicolus on broad mites and on castor bean and sunnhemp pollen. Exp Appl Acarol 60: 497-507

Sabelis MW (1990) How to analyse prey preference when prey density varies? A new method to discriminate between effects of gut fullness and prey type composition. Oecologia 82:289-298

Sabelis MW, Janssen A, Bruin J, Bakker FM, Drukker B, Scutareanu P, van Rijn PCJ (1999) Interactions between arthropod predators and plants: a conspiracy against herbivorous arthropods? In: Bruin J, van der Geest LPS, 
Sabelis MW (eds) Ecology and evolution of the Acari. Springer, Netherlands, pp 207-229

Sabelis MW, Janssen A, Takabayashi J (2011) Can plants evolve stable alliances with the enemies' enemies? J Plant Interact 6:71-75

Sarmento RA, Rodrigues DM, Faraji F, Erasmo EAL, Lemos F, Teodoro AV, Kikuchi WT, dos Santos GR, Pallini A (2011) Suitability of the predatory mites Iphiseiodes zuluagai and Euseius concordis in controlling Polyphagotarsonemus latus and Tetranychus bastosi on Jatropha curcas plants in Brazil. Exp Appl Acarol 53:203-214

Symondson WOC, Sunderland KD, Greenstone MH (2002) Can generalist predators be effective biocontrol agents? Annu Rev Entomol 47:561-594

van Maanen R, Vila E, Sabelis MW, Janssen A (2010) Biological control of broad mites (Polyphagotarsonemus latus) with the generalist predator Amblyseius swirskii. Exp Appl Acarol 52:29-34

van Maanen R, Messelink GJ, van Holstein-Saj R, Sabelis MW, Janssen A (2012) Prey temporarily escape from predation in the presence of a second prey species. Ecol Entomol 37:529-535

van Rijn PCJ, Tanigoshi LK (1999) Pollen as food for the predatory mites Iphiseius degenerans and Neoseiulus cucumeris (Acari: Phytoseiidae): dietary range and life history. Exp Appl Acarol 23:785-802

van Rijn PCJ, van Houten YM, Sabelis MW (2002) How plants benefit from providing food to predators even when it is also edible to herbivores. Ecology 83:2664-2679

van Veen FJF, Memmott J, Godfray HCJ (2006) Indirect effects, apparent competition and biological control. In: Brodeur J, Boivin $\mathrm{G}$ (eds) Trophic and guild interactions in biological control. Springer, Dordrecht, pp 145-169

Venzon M, Rosado MC, Euzébio DE, Souza B, Schoereder JH (2006) Suitability of leguminous cover crop pollens as food source for the green lacewing Chrysoperla externa (Hagen) (Neuroptera: Chrysopidae). Neotrop Entomol 35:371-376

Venzon M, Amaral DSSL, Perez AL, Rodríguez-Cruz FA, Togni PHB, Oliveira RFO (2011) Identificação e manejo ecológico de pragas da pimenta da cultura da pimenta. Informe Agropecuário, EPAMIG, Viçosa, Brazil
Venzon M, Oliveira RM, Perez AL, Rodríguez-Cruz FA, Martins Filho S (2013) Lime sulfur toxicity to broad mite, to its host plants and to natural enemies. Pest Manag Sci 69:738-743

Wäckers F, van Rijn PCJ, Bruin J (2005) Plant-provided food for carnivorous insects: a protective mutualism and its applications. Cambridge University Press, Cambridge

Weintraub PG, Kleitman S, Mori R, Shapira N, Palevsky E (2003) Control of the broad mite [Polyphagotarsonemus latus (Banks)] on organic greenhouse sweet peppers (Capsicum annuum L.) with the predatory mite, Neoseiulus cucumeris (Oudemans). Biol Control 27:300-309

Wong SK, Frank SD (2013) Pollen increases fitness and abundance of Orius insidiosus say (Heteroptera: Anthocoridae) on banker plants. Biol Control 64:45-50

Xiao Y, Avery P, Chen J, McKenzie C, Osborne L (2012) Ornamental pepper as banker plants for establishment of Amblyseius swirskii (Acari: Phytoseiidae) for biological control of multiple pests in greenhouse vegetable production. Biol Control 63:279-286

Marcus V. A. Duarte studies how different alternative foods can improve broad mite biological control.

Madelaine Venzon does research on alternative control of pest.

Marilia C. de S. Bittencourt works with biological control of mites.

Fredy A. Rodríguez-Cruz works on biological control of broad mites, focusing on pepper and physic nut.

Angelo Pallini works with ecology of food webs and biological control.

Arne Janssen investigates population dynamics and ecology of plant-inhabiting arthropods and has a strong interest in biological control. 